\title{
Christina Stead - An Internationalist and Cultural Mediator
}

\author{
Anne Holden Rønning \\ University of Bergen \\ achrroen@gmail.com
}

\begin{abstract}
Copyright $\odot 2017$ Anne Holden Rønning. This text may be archived and redistributed both in electronic form and in hard copy, provided that the author and journal are properly cited and no fee is charged, in accordance with our Creative Commons Licence.
\end{abstract}

\begin{abstract}
:
Christina Stead was one of the great Australian writers of the twentieth century. After a revived interest in her work in the 70s and 80s, Hazel Rowley's Biography (1993) and Chris William's Christina Stead: A Life of Letters (1989), as well as an issue of Southerly in 2003, Stead is in danger of being once again forgotten. Many of her texts, however, are relevant today as they express attitudes dominant in social media. It is perhaps fitting now in the twenty-first century that we evaluate how relevant her work still is in an age of transculturalism and globalization.
\end{abstract}

We see in some of her texts the same dissatisfaction with politicians, politics and social life expressed in current political events such as Brexit and the Trump phenomenon.

Key words: Christina Stead; internationalism; transculturalism; cultural mediator

Today we live in a world that in the course of a couple of decades has become dominated by a digital revolution. Issues which Christina Stead took up in her many novels and short stories written throughout the twentieth century are paramount in social media today; the young girl and her behaviour including social expectations and peer pressure; and questions of ethnicity, discrimination, stereotyping, and xenophobia. Border-crossings, 'multiple homes', as well as an ability to portray other cultures, and people's reactions to them, are characteristic features of Stead's work. With her piercing eye for detail she is able to inform us of what life was like for many, especially women, during this period.

Christina Stead was one of the great Australian writers of the twentieth century, and a writer for whom people and their portrayal was important. As Stead herself stated: "I confess that the study of personality is a private passion, with me" (Sage 1986: ix), and personality is always connected in some way to the social setting in which we live. After a revived interest in her work in the 70s and 80s with the Virago reprints, Hazel Rowley's Biography (1993) and Chris William's Christina Stead: A Life of Letters (1989), Stead seems to have been yet once again to some extent forgotten. Veronica Brady wrote on Christina Stead, and it is perhaps fitting in this volume in honour of her to consider, now in the twenty-first century in the light of contemporary affairs and changing critical views, the continuing relevance of her work. In many of her books she takes a clear political 
stance, whether it is the Labour Party in post-war England, or Communism in the USA in the MacArthur period. These attitudes are relevant for society today, a society where high on the political agenda is dissatisfaction with politicians, the establishment, and the way society works, as expressed in current political events such as Brexit and the Trump phenomenon.

\section{Transculturality and internationalism in Stead}

Both Christina Stead and William J. Blake, her lifelong companion and husband, were internationalists as Anne Pender states:

[T]he fact that she and Blake never set up a home base meant that they lived their lives as true internationalists, with a fervent interest in the future of the world, in social justice and a profound understanding of English, French and American political culture. (2003: 41)

In this article I should like to look at aspects of Stead as a transcultural writer, and her concern with identities and those who do not belong. Having lived, from the 1930s through to the 1970s, in different places on three continents, Australia, Europe and America, Stead experienced the diversity of the huge social and cultural changes that took place in the twentieth century. This provided her with a broad range of different people to draw on. As Geering comments in the afterword to Ocean of Story: "Christina Stead's books were written out of the times and places she lived in. Her writings followed her around the world" (538). Stead is remarkable for her ability to understand and portray the specific characteristics of a nation, and to mediate their cultures.

Christina Stead was aware of how much her internationalism framed her own identity as, after her return to Australia, she writes in a letter, April 1975. "I left my life lying on the shore of other countries and I came to Australia. No question of coming back - you can't come back. I am a migrant and must do my best without squawing but people expect, with an understanding smile, that I will say I am glad to be home, or something. I am not home" (MS 1AA: file 2, Letter to Stanley Burnshaw 20.4.1975). Such internationalists never settle. In "Why I am an Expatriate Writer" written when living in 34 Remsen Street, Brooklyn, New York Stead says, "I never felt an exile, an expatriate. I always felt at home, or at least the same as at home" (MS 4967, Box 15:6). She was a multicultural person, living in multiple homes and often with a sense of 'unhomely belonging. ${ }^{\text {i }}$ Apart from For Love Alone (1944) and Seven Poor Men of Sydney (1934), Stead's Australianness is not overtly apparent in her texts. This is clear in the quote above on her reaction on returning to Australia, and also in the fact that for many years Australians did not consider her as an Australian writer, and worthy of their prestigious literary prizes. As Angela Carter comments:

Stead is of that category of fiction writer who restores to us the entire world, in its infinite complexity and inexorable bitterness, and never asks if the reader wishes to be so furiously enlightened and instructed, but takes it for granted that this is the function of fiction. She is a kind of witness and a kind of judge, merciless, cruel and magnificently unforgiving. 
[Stead] has written novels set in cities in various countries as if she were native to them all. This phenomenon of ubiquity helps to explain her relative obscurity: she appears to acknowledge no homeland and has therefore been acknowledged by none until her return to her native country after almost a half-century of absence. (1982: 11)

In my opinion the views expressed by Angela Carter here epitomise a characteristic feature of Stead, and one that shows the transculturality of her writing. Her ability to depict accurately an environment is one of her strengths as a writer, but also places demands on the reader, as the constant mobility in her texts provides an approach to fiction writing not embodied in place, but rather character in place. If we look at her as a transcultural writer these gaps fill themselves, whether issues of gender or politics. Stead portrays characters moved out of their comfort zone of home into other multicultural environments to which they attempt to belong. Stead's apparent concern with love in its many facets for women should not prevent us from seeing the broader critique of society and cultural norms that lie behind. A good example is Letty Fox: Her Luck where Stead makes extensive use of satire to critique aspects of American society, especially sex and its links to money and power. Letty Fox: Her Luck takes the reader on a journey through different generations' reactions to life in the 1920-30s whether it be socialism which Solander, Letty's father, recommends (18), xenophobia (84), the Stock Market crash (116-17) Communism and the Second World War (443). Letty is a transcultural figure who seems to adjust to her many environments whether it be France Paris, England or America. She learns French and French customs while she and her sister lodge with a French peasant woman (124), adapts to life and schooling in England when the family move there, and finally in America becomes a promoter of free love, attends Communist meetings and talks of "Radicalism as the opium of the people" (3867). She expresses the diversity and hybridity of cultures that Edward Said speaks of in "The Clash of Definitions," his answer to Samuel Huntington's essay "The Clash of Civilizations" which looks at the issue from a binary point of view. Said opposes this binary view in the light of globalization and a world where multiculturalism is dominant and here to stay. As I have pointed out elsewhere "no one can live in another country or culture, or read extensively about other cultures, without being influenced and affected by it" (Rønning 2011:5). It is vision, scope, and setting not necessarily theme, which makes Stead a transcultural writer.

Transculturation, a term coined by Fernando Ortiz in the 1940s can be seen, not as a theory, but "a matrix through which a set of critical tools and vocabularies can be refined for the study of texts from a localized world, but institutionalised globally." ii One characteristic feature of transcultural literature is a global and glocal perspective on cultural and social codes something epitomised in Stead through the variety of characters and settings she depicts, and who often face a clash between the global and the local. ${ }^{\text {iii }}$ We can ask whether such people become "orphans of both cultures" as Ringrose suggests (2007: 24). They experience a feeling of 'unhomely belonging' as the life style chosen and familial traditions often make independence problematic, as well as identities. Referring to Gordon Mathews Priscilla Ringrose poses an alternative approach:

Mathews contends [...] that the global cultural supermarket is eroding the cultural norms propagated by the state. He believes that the taken-for-granted 
aspects of identity inculcated by the nation are shrinking and that the global cultural supermarket is replacing them. As a result of globalization, then, we could say that identity is becoming more and more of a choice. (cited in Ringrose 2007: 32)

Stead's female characters tend either to revolt against the standard norms or conform to them. Letty Fox is described as a person who in the manner of a chameleon changes identities in an effort to fit in, and not least to have relationships with men. She is on a picaresque journey to find herself. This is in contrast to Letty's mother who conforms to standard norms for women at the time. We can interpret Stead as favouring Letty's stance. There seems to be a generational gap where, as today, the younger generation's attitudes to gender roles are more ambivalent. Like Letty Fox Stead's characters are often portrayed as picking and choosing what elements of the new culture they will endorse. This can be paralleled today in the migrant situation, and at another level in peer pressure among teenagers, in particular encouraged by social media and reality shows. How far must we go in assimilating or integrating the diverse cultures that are part of our heritage and contemporary lifestyle? How different in fact are Letty Fox and other young people depicted in Stead's novels from young people today?

In Stead's writing transculturality takes the form of analyses of contemporary society from a multifocal point of view. We can consider Mary Pratt's 'contact zones' as applicable to Stead's work if we think of them as demonstrating that the very core of transculturation is the ability to move freely from one cultural stance to another, and give expression to the social spaces where cultures meet. Stead demonstrates time and again that despite our intercultural understanding we all have a cultural baggage which is never entirely abandoned in another setting, no matter how far we have travelled in time or space. For people such as Stead migration, whether voluntary or forced, is an essential part of life experience, a palimpsest. Her characters frequently give an impression of never being satisfied with their lives - always looking for something else, sometimes in a desperate attempt to be accepted.

Angela Carter posits that at an early stage in her writing Stead had "already established her characteristic milieu as that of the rootless urban intelligentsia, a milieu as international as it is peculiar to our century" (Carter 1982: 11). Carter is referring specifically to Seven Poor Men of Sydney but her comment is borne out by the constant debate between characters on social and political issues that we find in Stead's texts. Her characters are frequently cross-cultural, facing and living in changing socio-cultural contexts and perspectives, and reflecting thus the relation of these to their identities. For example, Elvira Western in The Beauties and the Furies (1936) has gone to Paris to escape her conventional marriage and the confines of English society only to find she does not belong in the Parisian cultural world of left-wing politics and political discussions in cafés either. It is one thing to be on "the socialist side in debates" at school (84), quite another to be part of the intellectually challenging political discussions conducted by her friends in Paris. One of this group is Marpurgo a wily, cunning, pseudointellectual Italian Englishman, and an inveterate talker. In this novel Stead manages to create an atmosphere of reality and credibility, characters sitting around in Parisian cafés dreaming strange intellectual fantasies. 
In an article on Alessandro Spina iv , Arrianna Dagnino rightly suggests that transculturality is a narrative expression of a state of being, and a rejection of "identitarian labelling" (2016, 5, 42). Literature is often the emotional expression not only of identities, but also of how those identities came to be formed. As such it has an emancipatory function and is a socialising force. There are many ways in which we can interpret and look at Stead's texts, whether as a satirical comment on people and stereotypes in the many places she lived and worked, or as an ironical and critical eye on politics, love, and women's position in society. However, looking at her texts through transcultural lens gives us a new understanding of her narrative skill in portraying these different environments and understanding of other people's culture and way of life. The hybridity of the transcultural and the cultural mobility of 'unbelonging' have taken over, sometimes giving an overall bleak picture of living in another country or culture, and the concomitant depressive feelings that often ensue. This is evident in the 'imaginaries' of the text, narrative expression, theme, setting and representation of characters. I would suggest Stead is an outsider and insider to her own original cultural background and to the societies and cultures about which she wrote. This provides her with a remarkable ability to distance herself from the text, and yet at the same time give an impression of having experienced the events narrated.

To illustrate some aspects of Stead's internationalism and transculturalism I have chosen to look at the stories about England in the 1950s, and her novel The Little Hotel with its mix of characters from different countries, both microcosms of contemporary life then. To do this Stead used character sketches much in the manner of Katherine Mansfield in her New Zealand stories, Undiscovered Country (1974). In this volume Ian Gordon has collected the stories Mansfield wrote about life in New Zealand, mainly from a child's point of view. The stories are vignettes and much in the same manner as we find in Christina Stead's stories there is no closure. To Stead writing was "essentially a social and communicative act" and she "saw her role as seeking to understand and to communicate this 'embroiled world' to the public" (Cowden 2003: 70). She regarded the short story as more than a literary form, "it is an ever-changing proof of man's universal need for expression. [...] it is the million drops of water that are the looking-glasses of all our lives" (1968: 449). They thus give us a momentary insight into or view of a person or place, but lack permanence, as expressed, for example, in descriptions of class escape in post-war Britain in Cotter's England. In the introduction to Ocean of Story Stead writes that "[a]ny treasury of story is a residue of the past and a record of the day" (1986: 3). Further that "It is the hope of recognising and having explained our own experience" (1986: 6-7). A vital element in stories is

genuine experience and a personal viewpoint [... since] [t]he virtue of the story is its reality and its meaning for any one person: that is its pungency $[\ldots]$ it is real life for everyone; and everyone can tell one.

$\ldots$

The short story can't wither and, living, can't be tied to a plan. It is only when the short story is written to a rigid plan, or done as an imitation, that it dies. It dies where it is pinned down, but not elsewhere." (1986: 7 and 10)

The inconclusiveness of her stories underlines this. She comments on people, their foibles and views. Stead's manuscripts confirm this, as well as Rowley's biography, both 
showing the extent to which Christina Stead used real-life people, often friends, as models for her characters.

\section{Stead in England}

Speaking of Cotter's England and Miss Herbert, the two novels set in England, Stephen Cowden states in his essay "Christina Stead and the Marxist Imaginary" that:

Stead offers a picture of England through an analysis of the two central political and social structures from which it is composed: Labour England and Tory England. These are the two worlds not just of English politics, but in the post-war period lasting up until at least the 1980s, these were the two worlds of English life. Stead's choice of character in this sense is thus concerned with the way particular individuals become the imaginative ground from which she portrays the social forces which make up 'England.' (2003: 71-2, emphasis in the original)

As Hazel Rowley points out: "In her [Stead's] fiction, personal relations were always grounded in the social and economic world" (1993: 255), as is seen in Letty Fox. This is especially apparent in Cotter's England where Stead has succeeded brilliantly in depicting the working class social codes in Newcastle and working class political views in London leaving us with the question of whether we really can leave our roots. In this text and in Miss Herbert Stead shows her mastery of different forms of English — what in my opinion makes her characters so alive, and yet poses problems for critics who may not recognize the finer nuances of linguistic diversity. The ability to adapt her narrative expression to the circumstances in which her characters find themselves, is part of the border crossing of transculturalism — language being a key element.

The short stories about England epitomize the situation in areas of London immediately post-war. We see a group of people of foreign descent struggling to come to terms with 1950s Britain - a Britain that was still recovering from rationing, which lasted into the early 50s, and the discrimination of foreigners that was prevalent after the war. Transculturalism is evident in the characters portrayed, as the ethnic mix, and boarding house environment gave Stead a diversity of people to portray. The views expressed in these stories written some sixty years ago are not that different from those experienced by many migrants and refugees today. All characters suffer from a sense of 'unhomely belonging' a key aspect being where you come from and whether you really belong in England. As Ann Blake has commented:

these three stories of landlords and tenants present a materialist social analysis of English life in the 1950s, a telling image of Stead's England. It is an unequal and divided society, a nation where economic frustrations and jealousy are expressed in racial and class hatred [and] the complacency of the middle-class, their snobbery, chauvinism and coldness. (1993: 155-6) 
Stead depicts ironically a deep distrust of other foreigners among the boarding house owners, including those who themselves are foreigners, exemplified on the occasion when Mr. Turtell berates his wife for having bought an English stove from someone who is not English: "The mere fact of his being a foreigner and not born here makes him inferior and induces him to pick inferior goods to sell" $(O S 473)^{\mathrm{v}}$. To show the diversity of people living that area of London Stead includes the fact that one of their lodgers, Hasma/Hassan is an 'oriental' who states specifically that he can never take up with an English girl because their moral views do not agree with his: "[ $\mathrm{t}]$ hey seem coarse to me" (OS 471). However, satirical and ironical Stead adds a twist as Hassam asks if his fiancée from Bengali, who is coming to London, can live with him in his room, as Mrs. Turtell's presence in the house will function as a chaperone!

Neither Christina Stead nor Blake liked living in England. Blake comments on life in Britain:

There is such hostility to life in England [...] Here, in the Euphoria of Imperialism [...] As the very anti-Semitic Mr. Eliot observed there are no great themes left to exploit, the notion of purpose is itself childish, all values are tricks, hope is an illusion, despair silly, living for the moment is too petty for comment, in other words there are no themes big or little. But I just don't believe that among 50 million people in the nursery of Chaucer and Shelley, that such things are possible. The other voices are simply given no hearing. But in an economic boom any there brains are at a discount and appetites at a premium. (Letter to Stanley Burnshaw, Sept 7, 1959)

And in another letter Blake comments on the dearth of intellectual life in Britain which is dull "outside the theatre" where "Behan and Wesker etc.," meet his approval.

England seems to have entered a Byzantine stage, full of clever and sophisticated and even nuance criticism, a rather distant, bored way towards creation, a feeling that values are dead and themes exhausted and that the upsurge of the Socialist countries is naïve, so adolescent as not to be worth much attention. I don't agree with Kenneth Tynan that the yawn is Britain's coat of arms but, compared to France [...] we are certainly a great mass of sterile self-congratulations on our ability to originate. Only in the social novel is there some rebirth of the "Thirties", as with Braine and Sillitoe. (Letter to Burnshaw December 6, 1960)

The coldness of life in England is echoed in the gossip between neighbours Gwen Jones and Rose Turtell in the short story "Accents." The English in general are seen as cold and aloof, something she discusses with Hassam who comments, "[t]he English are so cold and rude to foreigners. Especially orientals" (OS 464). Mrs. Turtell says the weather is no better, "I can't stand the cold in this country. It's worse than Russia, worse than New York" (OS 459) - a view we find again in Stead's papers. In "Street Idyll" Gill likes to sit on a park bench and talk to people, but finds this difficult as when he tries to start a conversation, the woman "did not answer, she seemed offended, we had not been introduced, this is England" (OS 399). The bench on which an old lady is sitting and which Jenny associates with age, is symbolic of the feeling of loneliness and nonbelonging that the characters emanate, their sense of 'unbelonging.' The two characters 
in "Street Idyll," (which some critics maintain is autobiographical), are fundamentally different, Gill is "a square-cut, dark man," Jenny, a "tall fair woman" but "[T]hey looked like strangers to each other; and they had never lost this look; reared in different countries, different traditions" (OS 401). Stead also has an interesting comment that it is not just language and looks which mark difference, but also ways of walking. Jenny, the protagonist in this story, is told that her way of walking gives her away as not being British — "It was your walk, your Australian walk" (i.e. a stride). "It's true, I saw an Australian in Tottenham Court Road the other day; it was his walk" (OS 401) — a remark which is also found in one of Blake's letters to her, and an interesting sociological comment on how not just body language, but even our normal conduct can identify us as the 'other'.

The story "Accents" is about the Turtell family who run a boarding house for lodgers but criticize all the time other people for not being sufficiently English. Mrs. Turtell/Rose Dubrovsky is Slav and "speaks English perfectly but has traces of a foreign accent" (OS 456), and her husband, Noel, is half- Spanish and half-German. In answer to his perpetual demand that they must integrate Rose comments: "John! Your mother is a foreigner, your father too. I am a foreigner. Aelfred and Boadicea were born in Buenos Aires" (OS 472). In other words none of them are of British descent, but John expects his children to be "more English than the English. That's why our children have such ridiculous names" (OS 463). The children are sent to a private school at great expense, where they are taught to speak with a 'proper' accent, and they are also given old English names, Boadicea and Aelfred. No one in the 40s or 50s would ever have given their children such names. The irony of this is lost on the parents, as they fail to understand that names are one of the criteria by which people identify others as being different and strange. "Accents" is a sad story of how a bright young woman abandons her planned medical career for love - a typical Stead characteristic - only to lead a life of dissatisfaction, as they are now in a "country [...] full of stuck-in-the-muds" (OS 461). How many of those who migrate from one country to another today are in the same situation? The question of ethnicity is also taken up in "1954: Days of the Roomers." Mr. Warren has a French mother and English father, whereas his wife was born in Lodz, Poland, marking them as foreigners. When her husband is ashamed of the fact that his children have foreign parents Mrs. Warren seems by contrast to accept the situation as unchangeable: "you know I will never lose my foreign accent and you have a foreign accent too, except in French!" (OS 404). Stead's portrayal of these families epitomises cultural conflict both in norms and the ability to speak the language and is one of the criteria that makes these texts transcultural.

One brilliant feature of "Accents" is how precisely Stead has depicted the characters the conversations between Rose Turtell and Gwen Jones is exactly the kind of gossip that was often heard on radio programmes in the 50s, such as Mrs. Dale's Diary. This allows Stead to write as an outsider, but also gives her much space for ironic and satiric expression. Her indication that this area of boarding houses and lodgers was populated by foreigners and not Londoners, brings to mind the ghettoization that has taken place, in particular in many European countries recently with the free flow of labour. There was more integration in the 50s, 60s, and 70s, not least because the vast majority of migrants were from former colonies and spoke English, whereas today linguistic equality is not the case. In the wake of Brexit the attitudes expressed in some of her English stories are paralleled by those heard in England today where people who have lived for years in Britain, even Irish people, are being asked if they should not go home. 
In "A Routine" the text concentrates on a couple, Noel and Caroline, who scheme on how to avoid paying rent. It illustrates the phoney renting system prevalent at that time in parts of London. Every time they get into severe debt they move, taking with them whatever they can from their lodgings. What is Stead saying about lodgers in London? The landlords are extortioning money from people - a fact — and the market is dominated by non-Brits, many refugees from Central Europe, but they are all considered suspect, especially those who are Jewish. "The Walkers are Jews: they're just spies for the landlords" (OS 420). What it does show is that the English were sceptical of foreigners, xenophobia was prevalent, and integration was not a subject talked about.

\section{The Little Hotel}

A useful tool for discussing transculturality in Stead is her short novel The Little Hotel. In the late 40s early 50s Stead and Blake lived in the Netherlands, France and Switzerland. This provided the background for this text with its residents from England, Switzerland, Belgium and Austria - a microcosm of Europe. Two of Stead's short stories, "The HotelKeepers Story" and "The Woman in the Bed" are interpolated into the text. The Little Hotel has a plethora of characters displaying aspects of the human condition, presented in an almost Chekovian manner, but one which also has something Pinteresque about it. Putting people together in a setting and seeing what happens reminds me of The Caretaker and The Birthday Party where the "conversation," if it can indeed be called that, reveals a lack of communication, a topic which is central to Pinter's work, as is also the relation between people.

Stead's reliance on her own source material is obvious in this text. If we look at her diary "The traveller's bed and breakfast" for the journey she and Blake took in Switzerland and France from September 1950 to April 1951 we find among her manuscripts extensive notes on the characters that they met, and which fit at times word for word with her descriptions of characters in the text. I am not suggesting that this story is necessarily autobiographical, far from it, but the relation between the two texts is indicative of Stead's narrative method (MS 4967 Box 15, folder 111).

The Little Hotel is a satire on 'genteel folk' of different nationalities living in Swiss hotels after the war. It is a cross-section of the guests in that kind of hotel at the time, delineating some aspects of society in the late 40s -post-war. As Geering comments, "The Little Hotel is essentially a study of a group of people, living an existence curiously poised between isolation and dependence" (1978: 464). In her manuscript notes on The Little Hotel Stead writes

The Ms of Mrs. Trollope and Mme. Blaise [the original short story] is a light thing, though a tone of pity perhaps goes through it -exiles, self-exiled, in a little hotel, people with sufficient money- except for the servants who are very poor. It is written up as a community, which in a way it was - it was small enough. (MS 1AA. April 15, 1973)

Those in The Little Hotel are shadows of the traditionally accepted, which is why Stead places them in a fourth rate hotel. The text is a kind of 'comedy of manners' that is, a 
satire of manners and affectations of a social group at whom Stead is poking fun. Judith Kegan Gardner writes that Stead in this book "displays a wide international gallery of eccentric figures" (2003:18) but they can also be seen as funny and stereotypical. The guests represent a mix of nationalities. Mrs. Blaise is Swiss from Basel and has acquired Nazi money through property. She lives in the hotel periodically to get away from her husband, the doctor. The mad, champagne loving Mayor of B. is supposedly Belgian, but uncertainty is expressed as to his real identity; Lilia Trollope is Euroasian, described by Madame Blaise as "That Asiatic" as "she is not one of us. You don't feel she's like you and me" (43). How like what we hear today in the twenty-first century. Lilia's 'cousin' Robert Wilkins, an ex-colonial from Malaya is originally from Yorkshire; Miss Abbey-Chillard with her "highbred insulting voice" (79) is English, fleeing from the Labour government in Britain, and complaining that the Bank of England refuses to give her full access to her money due to Labour government restrictions $(80-81,91)$. Lilia Trollope also complains that life abroad is useless but feels she has to keep up the honour of the English on the continent, and despite her origins refers to herself and others as "We English" (87). Racism is apparent in the fear expressed on seeing a coloured person, especially by the American Mrs. Powell. Stead utilizes this mix of nationalities for all it is worth, not least in her depiction of Princess Bili di Rovino, a rich American widow whose late husband was an Italian prince, and who has a 'singing' dog (105). In fact it howls. However, are these characters really eccentric, apart from the Mayor of B., who obviously suffers from mental delusion, and Mrs. Blaise who even wears her outdoor clothes in bed? These extraordinary people provide Stead with a host of anomalous multicultural and transcultural characters, not just foolish ones.

In many of her books Stead uses a rich variety of scene, incident, character and imagery. In this text the scope is more limited, but it is significant that the setting is in Switzerland where three languages and cultures meet and integrate typified in the servants; Clara from Zurich, the Italian sisters Luisa and Lina, and the German-Swiss housekeeper (OS 302). The text is a reasonably faithful picture of life for this group if we compare it with other similar stories, dealing as it does an expatriate milieu; rich ladies who dress as if poor; the war and communism; escape from the Labour government. In other words political undertones are present throughout. Using a story-telling technique, the narrator, the hotelkeeper Madame Bonnard, sets the tone in the very conversational manner in which she describes her life in the hotel, the guests and their habits, and her evaluation of them as people.

They are counting their pennies. They have some money, some are rich, all are getting on and getting anxious about their years; and besides them there are a few poor travellers, people without a home who go from one place to another, all over Europe; there are some refugees now settled with us; some collaborators who escaped in time after the war; then the night-club people and, in winter, the people going up the snowfields. (31)

Stead often uses the cinematic device of zooming in to convey a portrait or create a mood in her texts, clearly seen here in the episodes where Mrs. Trollope visits Madam Blaise in her room, and at the dinner party. Some critics think of the dinner party as the highlight of the novel, since it marks a change in point of view abandoning the first person narrative. However, in my opinion, it can rather be looked upon as a scene set with people from different countries where their own personality and national cultures come to the 
fore. It marks a change of point of view in the text, but it does not interrupt the flow, rather summarizes what we as readers have already surmised. A dinner party as the setting for a discussion of money and finances is also seen in The House of All Nations (1938) when Marianne and Aristide dine with the Hallers in Paris, and the description of the stuffed carp dinner provides the background for discussions about investments and banking, but which also emphasizes gender role differences. What better than a dinner to satirize and reveal the true nature of the characters and what their priorities are. Stead's irony and tongue-in-cheek approach is fascinating.

Stead also expresses views on capitalism and money, and The Little Hotel is no exception. Gardner suggests that the eccentrics are "not just foolish characters but oddly representative cogs in the complex machinery of global capital" (23). All the people in the hotel have real or imagined financial problems. Robert Wilkin has elaborate charts for investment and "cannot keep his hands off money" (126), and money becomes an important issue in conversations also between the women, but especially between Mrs. Trollope and Mr. Wilkin. He appears to have control of her money, which he is "investing," but it is never clear exactly how. Gardner sees Wilkins as the epitome of the machinery of capitalism seen from a postmillennial perspective, as today global capitalism can immobilise the individual. His transformation "from passionate lover to egocentric calculator [...] can be seen as a transition from a colonial to a multinational capitalist masculinity, while his apparent rationality and manly protectiveness mask his depredations on his mistress's assets" (2003: 25). However, passionate lover is not the way Wilkin is portrayed in the text, rather an unscrupulous person who preys on other people's resources to gain what he can for himself.

Thus in The Little Hotel Stead brings together some of the major themes in her work, love and relationships, money, and political undertones in the way they affect the persona depicted.

\section{Conclusion}

The creation of mood and atmosphere adjusted to the nationality and domicile of the characters is an essential feature of Stead's narrative expression. The strength of her novels lies in her character groupings and inter-relationships in diverse settings, as well as her sharp social observation. Focusing a transcultural lens on Stead shows her amazing ability to absorb and then portray narratively the situations and places in which she found herself. She depicts cultural encounters, border-crossings, and characters that are immersed in more than one culture, expressing it through narrative strategies and linguistic codes. We know from the manuscripts in the National Library, Canberra, Australia and The Harry Ransom Research Centre in Austin, Texas, that she made extensive notes and researched details for every book. She was not just a fiction writer, but a portrayer of life as fiction. She was not bound by place in her writing, but chose to depict what she saw and experienced in many countries and on several continents. Reading all Stead's work takes us on an international cultural journey over several decades of twentieth century history from widely different national and social settings and cultures, putting our own lives into perspective. 


\section{Works cited}

Carter, Angela. "Unhappy Families: Angela Carter on the Scope of Christina Stead's Achievement." Review of The Beauties and the Furies in London Review of Books. Vol. 4, no. 17, 16 (1982): 11-13.

Blake, Ann: “Christina Stead's English Stories” Southerly vol. 53:3, 1993: 146-160.

Cowden, Stephen. "Christina Stead and the 'Marxist Imaginary'." Southerly 63, 3: 2003, 63-75.

Dagnino, Arrianna. "Re-discovering Alessandro Spina's Transculture/ality in The Young Maronite." Humanities 2016, 5, 42. www.mdpi.com/journal/humanities.

Gardner, Judith Kegan. "Christina Stead and the Synecdochic Scam: The Little Hotel." Journal of the Association for the Study of Australian Literature. 2, 2003: 13-28.

Geering, R. G. "What is Normal? Two Recent Novels by Christina Stead." Southerly vol.38: 4 (1978): 462-73.

Huntington, Samuel. "The Clash of Civilizations." Foreign Affairs 72:3 (1993): 24-49.

Mansfield, Katherine. Undiscovered Country. The New Zealand Stories. Ed. Ian A. Gordon. London: Longman, 1984.

Matthews, Gordon. Global Culture/Individual Identity. London: Routledge, 2000.

Pender, Anne. “Guest Editor's Note. Christina Stead.” Southerly 63:3, 2003: 41.

Pinter, Harold. The Caretaker. (1960). London: Faber \& Faber, 1991.

--- The Birthday Party. (1959). London: Faber \& Faber, 1991.

Pratt, Mary Louise. Imperial Eyes: Travel Writing and Transculturation. London and New York: Routledge, 1992.

Ringrose, Priscilla. , "Beur' Narratives of Self-Identity." Readings of the Particular: The Postcolonial in the Postnational. Eds. Anne Holden Rønning and Lene Johannessen. Cross/Cultures 89. Amsterdam \& N.Y.: Rodopi, 2007, 21-37.

Rowley, Hazel. Christina Stead: A Biography. Port Melbourne: Heinemann Australia, 1993.

Rønning, Anne Holden. "Multiple Homes and Unhomely Belonging," Le Simplegadi. 2016, 14, 16: 50-60. http://all.uniud.it/simplegadi

--- . "Literary Transculturation and Modernity: Some Reflections." Transnational Literature. 2011: vol. 4, no.1: 1-10. http://fhrc.flinders.edu.au/transnational/home.html

Sage, Lorna. Introduction to The Salzburg Tales. London: Virago, 1986.

Said, Edward. "The Clash of Definitions: On Samuel Huntington," in Said Reflections on Exile and Other Essays, Cambridge, MA: Harvard UP, 2002: 569-90.

Stead, Christina. (1973) The Little Hotel. North Ryde: Sirius, 1988.

--- 1985. Ocean of Story. Victoria and Harmondsworth: Penguin, 1986.

--- Letty Fox: Her Luck. (1946) London: Virago, 1982. 
--- The Beauties and the Furies. (1936) London: Virago, 1985.

--- For Love Alone. (1944) London: Virago, 1986.

--- Cotter's England. (1966) London. Virago, 1985.

--- Miss Herbert: The Suburban Wife. (1976) London: Virago, 1992.

--- House of All Nations. (1938) Sydney: Sirius-Angus \& Robertson, 1988.

--- Seven Poor Men of Sydney. (1934) Bondi Junction, NSW: Imprint, 1999.

--- Talk at International Symposium on the Short Story, England. Kenyon Review XXX, (1968) 4: 444 - 450.

Williams, Chris. Christina Stead: A Life of Letters. London: Virago, 1989.

Christina Stead manuscripts in the Harry Ransom Research Centre, Austin, Texas. File 1AA: folder 1 and 2, Letters to Stanley Burnshaw.

William Blake's letters to Stanley Burnshaw. File 4. Harry Ransom Research Centre, Austin. National Library of Australia. Papers of Christina Stead, MS 4967: Box 15 (folder 111 and 113).

\footnotetext{
${ }^{\text {i }}$ See Rønning, 'Multiple Homes and Unhomely Belonging', Le Simplegadi 2016, 14,16: 50-60.

ii Definition used in the Transcultural and Literary Aesthetics Network, University of Bergen. www.uib.no/fg/transcult
}

iii “"Glocal' is a term coined by Roland Robertson, an amalgam of global and local” (Ringrose 2007: 22.) Priscilla Ringrose discusses the term in "'Beur' Narratives of Self-Identity: Beyond Boundaries and Binaries," in Readings of the Particular: The Postcolonial in the Postnational ed. Anne Holden Rønning and Lene Johannessen 2007.

iv " A contemporary Syrian author who became a naturalized Italian citizen,” (Humanities 2016, 5: 42)

v $O S$ stands for Ocean of Story.

Bio note: Anne Holden Rønning is Associate Professor Emerita at the University of Bergen, Norway. Her research areas and fields of publication are Women's Studies and postcolonial and transcultural literatures and ideas, especially from New Zealand and Australia. She has co-edited several volumes of essays in these fields notably Identities and Masks: Colonial and Postcolonial Studies (2001), Readings for the Particular: The Postcolonial in the Postnational (2007) and For Was I not Born here? Identity and Culture in the Work of Yvonne du Fresne (2010). She has also edited an issue of the online journal Otherness and some issues of the online journal Coolabah. She was chair of the European Association for Studies of Australia 2001-2005. She has also published in and co-edited two books with Mary Louise Kearney of UNESCO: Women and the University Curriculum: Towards Equality, Democracy and Peace (1996) Graduate Prospects in a Changing Society (1998). 